\title{
What is Nature IN THE Epoch OF THE ANTHROPOCENE?
}

Diana Soeiro ${ }^{1}$

(Institute of Philosophy, FCSH/ Universidade Nova de Lisboa)

Up until the early 1980s, the word "Anthropocene" was virtually unknown in the Western world. About then, biologist Eugene F. Stoermer (1934-2012) used it for the first time to refer to the impact and evidence for the human activities on planet Earth. But it was only later on when used by Nobel prize-winning, atmospheric chemist Paul Crutzen in 2000 that it started being widely used. Though many before Crutzen had taken an interest in reflecting on the consequences of the relation between human action and the environment (which can be traced back at least to George Perkins Marsh's Man and Nature, 1864), Crutzen was the first to consciously use the term as a scientific operating concept in order to describe the influence of human behaviour on the Earth's atmosphere in recent centuries as being so significant as to constitute a new geological epoch. ${ }^{2}$

What does Anthropocene mean? The term aims to denote a quantitative shift in the relationship between humans and the global environment, suggesting "(i) that the Earth is now moving out of its current geological epoch, called the Holocene and (ii) that human activity is largely responsible for this exit from the Holocene, that is, that humankind has become a global geological force in its own right."

\footnotetext{
1 dianasoeiro.drphil@gmail.com

2 Will Steffen, Jacques Grinevald, Paul Crutzen and John McNeill, "The Anthropocene: conceptual and historical perspectives", Phil. Trans. R. Soc. A 2011 369, doi: 10.1098/ rsta.2010.0327, published 31 January 2011, pp.843-844.

3 Idem, p. 843
}

Philosophica, 48, Lisboa, 2016, pp. 63-71. 
Despite the term being used frequently and widely in both academic circles and the media, it has yet to be acknowledged as a proper scientific concept that actually denotes a new epoch in the history of the Earth. The term is under evaluation by the Anthropocene Working Group in order to decide if there is evidence that we are at the beginning of a new epoch, and if this epoch truly has humankind as its main agent. If the evaluation is positive, then the term will have to be approved by the International Commission on Stratigraphy and then by the International Union of Geological Sciences. The process is expected to be concluded by $2017 .{ }^{4}$

Therefore, on one hand, when using the word Anthropocene, we should be aware that it can be premature (scientifically speaking) in the sense that it may never come to be acknowledged as an epoch. On the other hand, we cannot ignore that the word has come into existence, that it was conceptualized by Crutzen and that it has been widely acclaimed both academically and in the media. Crutzen not only described the definition but also a definition that had the underlined intention of an active proposal (that it should stand as a designation for a new epoch). If for no other reason than the last, the Anthropocene deserves to be reflected upon.

Having come to this point, we now ask: why is it that a concept concerning the science of geology (and in particular stratigraphy, the branch that studies rock layers and stratification) should concern the social sciences and philosophy?

The Anthropocene seems to inspire two opposing attitudes. One, where, although humankind's influence is changing the natural balance of the Earth, we will be able to pull through with recourse to new technologies, artificial intelligence and, eventually, adapting our minds and bodies, becoming half-human, half-machine. Another one, where end-of-the-world-like scenarios are described.

At this point, both attitudes are science fiction, or at best, good scripts for Hollywood movies. If the change is great enough to be considered an epoch, we do not (yet) know for sure. If humankind truly is the main agent, we do not know for certain. When did this change start? Different proposals are on the table but the consensus seems to be that it started with the Industrial Revolution.

4 Jan Zalasiewicz, "Working group on the "Anthropocene", Subcommission on Quaternary Stratigraphy Website. http://quaternary.stratigraphy.org/workinggroups/anthropocene/ (accessed February 29, 2016). Richard Monastersky, "Anthropocene: The human age", Nature 519 (7542). http://www.nature.com/news/anthropocene-the-human-age-1.17085 (accessed February 29, 2016). 
But again, the fact is that whether it is an epoch or not, whether it is called Anthropocene or something else, whether it started before or after the Industrial Revolution, changes have been occurring in the atmosphere at an accelerated pace and ecosystems are being strongly impacted to the point that life as we know it could be on the verge of changing dramatically. Climate change, according to an overwhelming majority of scientists $(97 \%)$, is a fact. ${ }^{5}$ Species are disappearing at a fast rate. ${ }^{6}$ This affects the temperature of the globe and rising sea levels, which have direct implications on what we eat, how we use the land and how we travel around, which in their turn affect energy resources and the economy. The whole concerns all areas of knowledge and the Anthropocene becomes an inevitable, and relevant, object of reflection for all of them.

In philosophy, in order to be able to process the meaning of the concept of the Anthropocene, one of the most obvious confrontations that can occur is putting it side-by-side with the classical concept of Nature.

Concepts need to be continually revisited so that their meaning can be renewed. The concept of Nature has been constantly revisited, probably since the beginning of humankind. There is therefore a huge imbalance between the old concept of Nature and the new concept of Anthropocene. In what way can it be relevant to confront these two concepts? Does the Anthropocene make the use of the concept of Nature obsolete? Is it time for Nature to reinvent itself again? Will Nature excuse the use of the concept of Anthropocene? Are they complementary?

In order to evaluate this, we will aim to identify where both concepts overlap, looking to see if there are any characteristics they have that assure their respective, separate identities.

Historically, religion is part of the discussion of the relation between man and Nature, not only if we think about the apocalyptic scenarios described in the Bible 7 , but also because of the attempt of modern thinkers to separate the law of God and the law of Nature. For example, Francis Bacon (1561-1626) claimed that the "Book of Nature" should be kept separated from the "Book of God" although they were complementary. ${ }^{8}$

5 The Consensus Project. http://theconsensusproject.com (accessed February 29, 2016).

6 Elizabeth Kolbert, The Sixth Extinction: An Unnatural History, Stuttgart: Picador, 2015.

7 Michael Northcott, "Eschatology in the Anthropocene: From the kronos of deep time to the kairos of the age of humans", in Clive Hamilton, Christophe Bonneuil, François Gemenne (eds.), The Anthropocene and the Global Environmental Crisis. Rethinking modernity in a new epoch, Abingdon, Oxon: Routledge, 2015, pp. 100-111.

8 According to Peter Harrison: "The notion that 'nature' was a book that could be 'read' and interpreted immediately brought to mind the authority of the other book, scripture. 
From that distinction, made during what is known as Early Modernity, another one derived, the one between the law of Nature (nature) and human law (culture). According to French anthropologist Philippe Descola (b.1942), this idea that nature is external to and separated from human beings is historically and culturally constructed in the West, and the dualism does not actually exist. This should therefore be reflected epistemologically. Having studied under Lévi-Strauss (1908-2009), Descola in his book Beyond Nature and Culture (Par-delà nature et culture, 2005) claims that through both interiority and physicality all cultures are able to acknowledge each other as equals while ascertaining their difference. This means that an epistemological change is necessary in the sense that it is not possible to continue to use homogeneous categories for varying cultures. More recently, Brazilian anthropologist Eduardo Viveiros de Castro (b.1951), who also studied under Lévi-Strauss, made a similar claim (though using a different conceptual framework from Descola's). ${ }^{9}$

According to Bruno Latour (b.1947), the concept of nature is an empty one. No one knows exactly which objects in the world it designates in the sense that it designates a long chain from the stars to the smallest bacteria underground. Therefore, a discourse that defends nature is politically senseless because politics already takes care of real-life situations in an effort to bring a balance between social and natural entities. This means that in politics the dualism is overcome because in politics nature and society are inseparable and indiscernible. ${ }^{10}$ In a similar direction, Timothy Morton (b.1968) claims: "Ecology may be without nature. But it is not

If the realm of nature could be argued to be another religious authority that shared some features of the other book, then its study could be encouraged." Peter Harrison, "“The Book of Nature' and Early Modern Science" in Klaas van Berkel, Arie Johan Vanderjagt (eds), The Book of Nature in Early Modern and Modern History, Leuven: Peeters, 2006, p. 4. The author claims that in the early modern period there is a prevalence of the "book" as a metaphor and a corresponding absence of "mirror" metaphors. "(...) this is in part because 'mirror' is visual and 'book' is verbal, and in this difference lies one of the defining features of the transition from the medieval to the modern era. The religious significance of the metaphors also undergoes a parallel shift. As a modern book, nature is not so much the medium through which we perceive the divine image as it is the basis of a logical argument from which we indirectly infer the divine wisdom and goodness." Idem, p. 6.

9 Eduardo Viveiros de Castro, Cannibal Metaphysics, Minneapolis, MN: Univocal Publishing, 2014.

10 Bruno Latour, Politics of Nature: How to Bring the Sciences Into Democracy, Harvard: Harvard University Press, 2004. 
without us". ${ }^{11}$

With the Anthropocene, whether the concept of nature is obsolete (Latour) or complementary with that of culture (Descola and Viveiros de Castro), we seem to be thrown back into the early stages of modernity, to the "Book of God" - "Book of Nature" dualism. Either we assume defeat and face the Anthropocene as "a culmination of a history of two centuries of conscious destruction" 12 or we continue striving for perfection by conquering nature as Bacon encourages us to do in New Atlantis (1624), a view supported by Ulrich Beck (1944-2015) and contemporary eco-moderns like Erie C. Ellis and Mark Lynas (b.1973), by using knowledge and technology. What both options seem to have in common is belief and, far from being an either/or, they seem to be complementary. The Earth's imminent destruction can be believed to be God's will, which belongs to the "Book of God" narrative, and we can try to avoid/ delay it by working on the "Book of Nature" narrative (science). A concrete example of this complementary approach is the Satoyama Initiative which, having started in Japan, has been spreading globally since 2009. The official name of the Initiative is IPSI, the International Partnership for the Satoyama Initiative, and it aims to promote "collaboration in the conservation and restoration of sustainable human-influenced natural environments (Socio-Ecological Production Landscapes and Seascapes: SEPLS) through broader global recognition of their value". This means creating societies in harmony with nature. ${ }^{13}$

In order to identify the key element behind this fake dualism, this either/or, between the "Book of God" and the "Book of Nature", we must identify the intention behind these complementary narratives. We claim that the intention is spirituality.

What does "spirituality" include and what does it exclude? Spirituality differs from the human activities of thinking and feeling. The first implies an intellectual exercise that uses words and concepts while the second deals with emotions and traditionally concerns the field of psychology. By spirituality we are not referring to a moral system, which implies a set of rules that a group of people have created and agreed upon following. We also do not identify spirituality with ethics, which encompasses the set of principles by which each person rules his/her actions. By spirituality we understand

11 Timothy Morton, Ecology Without Nature: Rethinking environmental aesthetics, Cambridge, MA and London: Harvard University Press, 2007, p. 205.

12 Jean-Baptiste Fressoz, "Losing the Earth Knowingly: Six environmental grammars around 1800", op. cit., p. 82.

13 Satoyama Initiative Website. http://satoyama-initiative.org (accessed February 29, 2016) 
inner awareness. Inner awareness, whether understood in the context of a religious institution or individually (as it tends to be exercised exclusively in modern times), is a process that cultivates a constant state of curiosity, turned inward to oneself, and that when fully successful maintains one in a state of openness towards what is happening around one and simultaneously in a state of inner dynamic suspension. The well-known Greek aphorism inscribed in the forecourt of the Temple of Apollo at Delphi, "Know thyself", points to a similar dynamic that we here describe as "spirituality".

In 2015, Pope Francis (b.1936), the highest ranking reference for the Catholic Church, decided to write an encyclical addressing the environment and human ecology as he considered it a priority topic. In it, the word "nature" is mentioned 82 times. ${ }^{14}$ The Anthropocene is not referred to directly although there is a sentence that clearly alludes to a similar conception, which coincides with the justification of the use of the prefix "anthropo" in Anthropocene: "the Bible has no place for a tyrannical anthropocentrism unconcerned for other creatures." 15 This sentence concludes a rationale about why "[t]he laws found in the Bible dwell on relationships, not only among individuals but also with other living beings." Animals, nature, people and the environment should be respected and their interests should prevail over human greed. Thus the encyclical aims to contribute to "an ecological spirituality".

In 1968 Islamic philosopher Hossein Nasr (b.1933) wrote The Encounter of Man and Nature: The Spiritual Crisis of Modern Man, and in his Preface to the 1989 edition, he claimed that the bond between man and nature was being broken due to man's "loss of the dimension of inwardness" 16 and, more importantly, that it was crucial to bring "to the fore the spiritual dimension and the historical roots of the ecological crisis" instead of "reducing all reality to the physical domain". ${ }^{17}$

In a globalized world where neoliberalism, which has little or nothing to do with spirituality, prevails, the fact that distinguished people come into the spotlight to declare that at its core the relation between man and nature concerns spirituality is highly relevant. Both are religious men and

14 Pope Francis, Encyclical, 2015. http://w2.vatican.va/content/francesco/en/encyclicals/ documents/papa-francesco_20150524_enciclica-laudato-si.html (accessed February $29,2016)$

15 Idem.

16 Seyyed Hossein Nasr, The Encounter of Man and Nature: The Spiritual Crisis of Modern Man, Chicago: ABD International Group, 1989, p. 3.

17 Idem, p. 4. 
perhaps their views may be considered unscientific, but it is significant to know that there is an acknowledgement in contemporary society that spirituality has a role to play when it comes to re-evaluating man's relation with nature - with or without the Anthropocene.

We say it is significant because at the other end of the spectrum there are many working hard and putting in long hours to be the best they can at what they do while actively contributing to the Anthropocene's previously mentioned "quantitative shift in the relationship between humans and the global environment" - which is not so scientific in its intention either. Some do so, consciously. Others either have no awareness or their harsh living conditions do not enable them to be aware. ${ }^{18}$

To Hossein Nasr, the loss of metaphysics in the West has broken the link between man and nature. We go back to the classical distinction between science and wisdom. We may have the information and know the facts, but what do we do with them? If the driving force behind all the information we have available is something other than a fruitful intention, we will not be able to "prevent this domination from becoming sheer self-annihilation." 19

In order to preserve nature as a relevant concept, it is necessary to think of it through the concept of spirituality. Each person who is persuaded to engage in a process of inner awareness will find destruction of what surrounds him/her impossible. This may sound somewhat underwhelming to those who expect more out of a scientific approach and we are aware that it is a concept that is in stark contrast to the prevailing acceleration generated by neoliberalism and the fast-paced, endless, scientific production - which perhaps explains why the use of the concept of nature has been in decline in the last few decades. By arguing for spirituality in the face of the Anthropocene (yet to be confirmed), we are arguing first and foremost for the need to slow down in order to make wisdom blossom out of science. Perhaps this solution is taking the long road but imposing laws and regulations that people do not relate to and, above all, that they do not understand or want to engage with (however well-intended they are) seems to have a lower impact than the situation demands. Laws and regulations that protect the environment will only have an impact when they reflect each human being's inner awareness. This translates as a common platform for humankind ${ }^{20}$ where we all agree that destruction is not the purpose of

\footnotetext{
18 François Gemenne,"The Anthropocene and Its Victims", op. cit., pp. 168-174.

19 Seyyed Hossein Nasr, The Encounter of Man and Nature, p. 83.

20 Edmund Husserl, "Phenomenology and Anthropology", in Shorter Works, Sussex:
} 
humans. A spiritual approach to the Anthropocene can greatly contribute to this. Although this may seem utopian, the experience of acceleration, as physics teaches us, always ends up translating into the feeling of standing still. The Earth is moving at 1670 kilometres an hour right now ${ }^{21}$ as you read this, and you do not even know it. You are experiencing utopia at first hand. Whether aware or unaware, eventually we will have to stop.

University of Notre Dame Press and The Harvester Press, 1981, pp. 315-323.

21 NASA, National Aeronautics and Space Administration Website. http://image.gsfc.nasa. gov/poetry/ask/a10840.html (accessed February 29, 2016) 


\begin{abstract}
The epoch of the Anthropocene is on the verge of becoming scientifically acknowledged by the science of Geology. In what way does this concern Philosophy? In this paper, we evaluate how the new concept of the Anthropocene contrasts with the classical concept of Nature, aiming to identify the territory of both. In order to do this we take as our starting point the approach of Francis Bacon (1561-1626) which separates God and Nature. This later translated into the separation of Nature and Culture. The latter dualism is contested by Philippe Descola (b.1942) who defends the convergence of both. Bruno Latour (b.1947) and Timothy Morton (b.1968) consider the concept of nature as obsolete. Ulrich Beck (1944-2015), Erie C. Ellis and Mark Lynas (b.1973) claim that science will be able to cope with whatever changes the Anthropocene brings. We consider that all these claims, albeit apparently contrasting, are grounded in belief and as a counter-proposal we aim to bring to the table the concept of spirituality as essential to re-evaluate what Nature is today in the light of the Anthropocene.
\end{abstract}

Key-words: Anthropocene-Nature - Culture - science - spirituality

\title{
RESUMO
}

A época do Antropoceno está prestes a tornar-se cientificamente reconhecida pela Geologia. Em que medida isso diz respeito à Filosofia? Neste artigo, avaliamos como é que o conceito de Antropoceno contrasta com o conceito clássico de Natureza, tendo por objectivo identificar o território de ambos os conceitos. Para isso, tomamos como ponto de partida a aproximação de Francis Bacon (1561-1626), que separa Deus e Natureza, o que mais tarde se traduziu na separação entre Natureza e Cultura. Este último dualismo é contestado por Philippe Descola (n.1942) que defende a convergência de ambos. Bruno Latour (n.1947) e Timothy Morton ( $n$.1968) consideram o conceito de natureza obsoleto. Ulrich Beck (1944-2015), Erie C. Ellis e Mark Lynas ( $n$. 1973) defendem que a ciência estará à altura de quaisquer mudanças que o Antropoceno traga. Consideramos que todas estas afirmações, ainda que aparentemente contrastantes, assentam em crença e como contraproposta temos por objectivo trazer à discussão o conceito de espiritualidade como indispensável para reavaliar o que a Natureza é, hoje, à luz do Antropoceno.

Palavras-chave: Antropoceno - Natureza - Cultura - ciência - espiritualidade 